\title{
ANALYSING 'CLASSICAL MUSIC RENDERED INTO WORDS' IN ANGLOPHONE FICTION AND ITS TRANSLATIONS
}

\author{
TEREZA MARKOVÁ \\ Charles University, Prague, Czech Republic
}

\begin{abstract}
Many fiction writers have tried to convey classical music, whether a particular composition, a particular interpretation as perceived by the listener, the performer or the author, the process of practising, rehearsing and composing music, the way notation speaks to us, or any other aspect of the extralingual musical reality transferred into words. However, not much has been written about the complexity of intersemiotic translation of 'music into words' in novels and short stories. This paper introduces two models for translation analysis of (Anglophone) musical fiction and its translations. The first model consists of a list of criteria for analysing the way the English-speaking writers render music into their mother tongue; the criteria are further applied to an excerpt from Vikram Seth's musical novel An Equal Music. The second model describes the process of analysing translations of musical fiction into other languages, aiming to find out whether the translators of this specific genre just follow the principles of interlingual translation or whether the differences between the two languages force them to perform intersemiotic translation of their own.
\end{abstract}

Key words: musical fiction, intersemiotic translation, translation analysis, Vikram Seth, An Equal Music

\section{INTRODUCTION}

Music and literature, two art forms engaging the senses and arousing emotions, have always been closely related even though their 'languages' quite differ. Poetry is a clear example of this close relationship - its rhythm and sound patterns remind us of music, and there have been many poems set to music in the history of 'classical' songs. As the novel started developing, it, too, came to be influenced by music: Lawrence Sterne's 1759 novel, The Life and Opinions of Tristam Shandy, Gentleman, is often considered to be the very first 'musical novel' although its musicalization does not go beyond musical metaphors.

The link between music and fiction has become more frequently recognized and exploited throughout the twentieth and twenty-first centuries. Music has become a source of inspiration, a tool for adding shades and tones to 
the atmosphere, for depicting the characters' personalities, portraying feelings and emphasizing major turning points in the story-line, and a model for structural and stylistic aspects of writing. An independent genre called musical fiction has developed, treating music as the paramount theme of novels and short stories. This genre, or sub-genre, deals with music and musicians, uses musically poetic and sound-centred language, and works with rhythmic patterns, tempo changes and other inherently musical qualities (as is the case with An Equal Music by Vikram Seth, Doctor Faustus by Thomas Mann, Bel Canto by Ann Patchett, and Music and Silence by Rose Tremain).

Though there exist quite a few stylistic studies analysing musical aspects in some of these works (see for example June Salz, 1955; Steinberg, 1982; Ditsky, 1983; Caswell, 2005; Moynihan, 2016), intersemiotic translation analysis of the ways authors translate music into their mother tongues has never been attempted. The same applies to the 'shadow area' of translating musical passages and texts from one language into another - there has been no research into the possible overlap of interlingual and intersemiotic translation caused by the system differences across languages and, more specifically, across the musical jargons in various languages. These differences, often calling for concretization/ abstraction, along with the need for a language that would reflect the real slang of musicians and be understandable to laymen at the same time, may require the translator to go back to the process of 'rendering music into words'; in other words, to perform their own intersemiotic translation within the boundaries of the 'proper', interlingual one for the sake of offering their readers the same experience readers of the original have enjoyed.

Based on the translation analysis models I proposed in an article published in AUC Philologica - Translatologica Pragensia (Marková, 2019), this paper aims to examine the process of intersemiotic translation in a selected passage from Vikram Seth's novel An Equal Music, and to further explore the overlap of the interlingual and the intersemiotic in musical fiction translations.

\section{ANALYSING MUSIC RENDERED INTO WORDS}

Unlike interlingual translation analysis, intersemiotic translation analysis cannot be done solely by focusing on the semiotic layers of the text, that is, morphological, phonetic and rhythmical. Intersemiotic translation analysis requires us to assess and compare the effect of a piece of music (whether in notation, or while being created, performed or listened to) with its depiction in words. Following Aguiar and Queiroz (2009) who have adapted Pierce's triadic model for the purpose of their model of intersemiotic translation, we can adjust the triadic model to suit our needs, replacing the representamen with a piece of music, the object with a piece of writing conveying music, and the interpretant with the reader/listener on whom the two works should have the same effect (Marková, 2019).

Nevertheless, this effect is hard to assess. An inspiration can be found in an article by Salmani and Eghtesadi (2015), who outlined their criteria for analysing 
intersemiotic translation of cover designs in retranslated classic novels. Similarly, we can draw up a list of criteria for analysing intersemiotic translation of music into words, which reads as follows (Marková, 2019):

1. The aspect in mind: What aspect of the musical world does the author try to capture?

2. Rhythm, tempo: To what extent does the rhythm of the text evoke the rhythm of the piece of music? How important is it when we consider the effect the text has on the reader? Do the sentences become shorter when the piece of music becomes swifter or rhythmically richer?

3. Abstractness versus concreteness: Does the author write about technicalities' and does he/she use terminology? Or does he/she, with the help of poetic language, focus on the feelings the piece of music evokes so that the exactness of the musical terms is sidelined? What kinds of expression does the author use?

4. Overall atmosphere: What is the atmosphere of the whole passage? Is it similar to the atmosphere of the music? Is the music in harmony with the mood of the characters and/or the atmosphere of the place where the story takes place, or is there a strong contrast between the two, with music stirring new emotions?

5. Context and purpose: What is the context and what is the purpose of the passage? Is it to make the text more poetic, or, for example, to show how the characters and their relationships develop?

6. Type of translation: Did the author write from memory, referring to music only vaguely? Or did he/she focus on the notation or a certain interpretation, truly 'translating' the piece of music into words?

The categories are rather wide - one must take into account that there are many variables and that the 'unlimitedness' of the analysis should reflect the 'unlimitedness' of both music and languages. The criteria are not meant to be followed blindly but to serve as a (rough) guide that can be adapted to the needs of the text in question.

\section{MUSIC RENDERED INTO WORDS IN VIKRAM SETH'S AN EQUAL MUSIC}

An Equal Music (1999) by the post-colonial writer Vikram Seth is one of the world's most acclaimed musical novels. It tells the story of Michael and Julia, a violinist and a pianist, who used to be in love with each other during their college years in Vienna and now meet again in London, only to find out that the old feelings have not disappeared during their years apart despite the fact that Julia has got a husband and a son. The story is told from Michael's point of view; we follow his emotional turmoil, watching him practise the violin, rehearse and perform with his string quartet, and listen to recordings. 
In the excerpt from the novel chosen for this analysis (the first two paragraphs of chapter 2.4), we see Michael listening to a recording of Beethoven's string quintet:

Without washing the Serpentine off myself, I put the string quintet on. The sound fills the room: so familiar, so well-loved, so disturbingly and enchantingly different. From the moment, a mere ten bars from the beginning, where it is not the piano that answers the violin but the violin itself that provides its own answer, to the last note of the last movement where the cello, instead of playing the third, supports with its lowest, most resonant, most open note the beautifully spare $\mathrm{C}$ major chord, I am in a world where I seem to know everything and nothing.

My hands travel the strings of the $\mathrm{C}$ minor trio while my ears sing to the quintet. Here Beethoven robs me of what is mine, giving it to the other violin; there he bequeaths me the upper reaches of what Julia used to play. It is a magical transformation. I listen to it again from beginning to end. In the second movement it is the first violin- who else?- who sings what was the piano's theme, and the variations take on a strange, mysterious distance, as being, in a sense, variations one degree removed, orchestral variants of variations, but with changes that go beyond what could be explained by orchestration alone. I must play this with the Maggiore, I must. If we're simply playing it through with a friendly viola, Piers will surely not mind my being first fiddle for once. (Seth, 1999: 68)

\section{THE ASPECT IN MIND}

Seth translates a genuine piece of music: Beethoven's String Quintet in C minor, Op. 104 (an authorial arrangement of his Piano Trio in C minor, Op. 1 No. 3), recorded by Suk Quartet with Karel Špelina playing the guest viola and published by Supraphon Music Publishing in 1976. The listener here is the main character of Michael, an informed, musically educated person, an erstwhile performer of the Piano Trio, and a prospective interpreter of the String Quintet.

\section{RHYTHM, TEMPO}

As Michael puts it, he feels like being 'in a world where I seem to know everything and nothing'. His child-like awe is reflected in Seth's stylistic choices. Long sentences are interspersed with short ones, simulating the tendency to point out interesting particulars while being carried away by the total uniqueness of the experience, and brimming with all the things the author wants to share with the reader. A similar effect is created by triads (lowest, most resonant, most open note; so familiar, so well-loved, so disturbingly and enchantingly different) and a parallelism (here Beethoven robs me of what is mine, giving it to the other violin; there he bequeaths me the upper reaches of what Julia used to play) - both these 
devices make the text rhythmical. The way Seth treats the length of his sentences seems to correspond with the themes of the first movement of the Quintet where short, slow and simple motifs (analogous to the short and simple sentences that we tend to read in a rather slow manner in this excerpt) alternate with longer, swifter and more complicated passages of music (analogous to the long and complicated sentences that leave us slightly out of breath).

\section{ABSTRACTNESS VERSUS CONCRETENESS}

The excerpt is an illustration of a mix of abstract and concrete expressions. While Seth does not avoid terminology and technical aspects of the composition (talking, for example, about the lowest, most resonant, most open note the beautifully spare C major chord or the upper reaches [of the piano]), he also uses metaphors (derived mostly from formal vocabulary the semantics of which creates a unique atmosphere, such as in bequeath or take on a strange, mysterious distance, a magical transformation) and deliberately puts 'music-related words' into a poetic context (as in the piano that answers the violin or my ears sing to the quintet). As the examples in brackets show, the effect of the text is chiefly derived from the metaphorically loaded verbs and adjectives Seth chooses.

\section{OVERALL ATMOSPHERE}

The passage evokes both nostalgia and excitement - Michael compares what he hears to what he used to play with Julia, remembering the times when they were together. At the same time, he is thrilled with the arrangement and the idea that he might be able to play it with his quartet. Since this particular composition is central to the story, there is no need to assess whether the atmosphere of the String Quintet corresponds with Michael's mood and the overall atmosphere of the passage; the translation of music is used to accent Michael's emotions relating to what the Quintet means to him rather than to what it could stir in him perse.

\section{CONTEXT AND PURPOSE}

Despite its obvious lyrical nature, the passage is not just a vehicle for making the novel more poetic. Michael listens to the recording because of the sentimental value the Piano Trio has for him, and it makes him want both to reconnect with Julia (whom he saw on the bus a few days earlier, for the first time in years) and to play the String Quintet with his colleagues (the latter becomes a source of tension between him and his quartet later in the story). Seth therefore uses the translation of music into words as one of the turning points in the novel.

\section{TYPE OF TRANSLATION}

As shown above, the String Quintet is truly translated into words. It is clear that the writer had to listen to and/or study the score of both the Piano Trio 
and the String Quintet quite closely to be able to describe some of Beethoven's arranging techniques and the final chord.

\section{ANALYSING TRANSLATIONS OF MUSICAL PASSAGES}

Although there are many translation analysis models, none of them fully meets the specific needs of musical passages that are often bound to exhibit a high degree of abstraction. While creating such a model, one must pose the questions it is supposed to answer. In our case, the main questions are as follows (Marková, 2019):

- How does the translation stand when read by a person unaware of the original?

- How does the translation stand when compared to the original?

- What is the position of the translated work in the literary canon of target culture? How has the translated work been received?

In the light of these questions, a combination of Toury's (1995) three-phase methodology (reading the target text; comparing the source text and target text; and reconstructing the translator's decision-making process) and two additional phases proposed by Berman (1995) (understanding the translator and his/her time; and formulating recommendations for future translations) seems to be the best approach possible (Marková, 2019).

Since one of the research questions (along with Toury's model (Toury, 1995)) requires the analyst to assess how the translation stands when read by a person unaware of the original, one must read the translated text before proceeding to read the original. The fact that a reader educated in literature and/or translation is what Eco (1979) would call a 'Model Reader' does not interfere with the analysis; it is not the aim to examine the text through the eyes of the 'common reader', but to familiarize oneself with the translation without knowing the original.

Based on this requirement, the whole process of analysing musical fiction and its translations can be divided into the following nine phases (Marková, 2019):

1. Reading the target text: Does the translation comply with the language and cultural norms of target culture?

2. Analysing the source text using the first model.

3. Analysing the target text using the first model, comparing the results.

4. Identifying translation problems and their solutions: As Toury (1995) says, every text consists of the invariant and the variant. The aim is to find out whether the invariant is maintained in the translation and how the variant is treated; then we can assign categories to the translation shifts depending on the model we choose (for example Popovič, 1968; Catford, 1978; Lefevere, 1992; Toury, 1995; Levý, 2012).

5. Identifying strategies used for solving the problems: Identifying the shifts and categorizing them is not enough; we must try to retrace the decisionmaking process that has led to them. In the analysed excerpt, the final 
chord is described as [the] lowest, most resonant, most open note the beautifully spare $C$ major chord. The term open note can mean either a note with an outline head instead of a solid one, or the aliquot harmony which is a natural part of the basic tone of an instrument. Should the novel be translated into Czech, for example, the translator would have to listen to the Quintet or read the score to choose the right meaning since there is no equally ambiguous Czech term. This semantic strategy would be what Chesterman (1997) calls abstraction change in his classification of translation strategies - a shift from a more abstract term to a more concrete one.

6. Gathering information about the translator: This is an inseparable part of the previous phase. The translator's background is crucial in the decisionmaking process; the competencies required for translating musical fiction usually include musical education and the ability to work with rhythm and textual aspects of sound. There are also two other key factors influencing the final product: the cultural and social characteristics of the period in which the translation was created, and the translation project or concept, i.e. for whom and how the translation was created (Berman, 2009).

7. Interlingual and/or intersemiotic translation: On the basis of all the results and information collected during the previous phases, one can determine whether the translation was strictly interlingual or whether a combination of interlingual and intersemiotic translation was applied. If, for example, the Czech translator of An Equal Music was familiar with music, performed the abstraction change as described above (see step 5) and chose the right meaning (which is 'the aliquot harmony which is a natural part of the basic tone of an instrument' in this case), he/she would perform the act of intersemiotic translation of his/her own, thus applying both interlingual and intersemiotic translation at the same time.

8. Assessing reception of the translated work: The translation quality (both of the whole work and of musical passages) can affect how the work is received in another culture (while bearing in mind that such a specific genre as musical fiction attracts a rather small readership).

9. Formulating recommendations for future translations: Having analysed a certain number of novels and short stories, we can formulate recommendations for future translations regarding the problems of how to choose a book to be translated and a suitable translator for it, how to treat musical passages, and what to avoid when translating and publishing musical fiction.

\section{CONCLUSION}

Since analysing musical fiction requires an interdisciplinary approach, completely new models have had to be created. The models proposed can be applied to both 
original and translated pieces of writing in any language, and can be adopted for the purposes of other intersemiotic translation analyses as well.

As the brief sample analysis of the excerpt from Vikram Seth's novel $A n$ Equal Music has indicated (and as has been proven by other pieces of musical fiction analysed for the purpose of my oncoming dissertation), translating music into words is a complex task requiring an author educated in music. In return, the musical passages can enrich the prose with a vast range of emotions, powerful poetics, original imagery, deeper portrayals of the characters' feelings and train of thoughts, and underivative settings for plot development. Despite readers' potential fears, musical fiction does not have to be only for musicians; Seth teaches us that it can be understandable for everybody and offer an intense experience even to complete laymen - with a special 'cherry on top' for those who can detect its deeper layers.

\section{REFERENCES}

Aguiar, D. and Queiroz, J. (2015) Towards a model of intersemiotic translation. In P. P. Trifonas (ed.) International Handbook of Semiotics (pp. 201-215). Dordrecht: Springer.

Berman, A. (1995) Pour une critique des traductions: John Donne (Toward a Translation Criticism: John Donne). Paris: Gallimard.

Caswell, R. (2005) A musical journey through John Steinbeck's The Pearl: emotion, engagement, and comprehension. Journal of Adolescent \& Adult Literacy, 49 (1): 62-67.

Catford, J. C. (1978) A Linguistic Theory of Translation: An Essay in Applied Linguistics. Oxford: Oxford University Press.

Chesterman, A. (1997) Memes of Translation: The Spread of Ideas in Translation Theory. Amsterdam/Philadelphia: John Benjamins.

Ditsky, J. (1983) 'Listening with supersensual ear': music in the novels of Willa Cather. The Journal of Narrative Technique, 13 (3): 154-163.

Eco, U. (1979) The Role of the Reader: Explorations in the Semiotics of Texts. Bloomington: Indiana University Press.

June Salz, P. (1955) Peacock's use of music in his novels. The Journal of English and Germanic Philology, 54 (3): 370-379.

Lefevere, A. (1992) Translation, Rewriting and the Manipulation of Literary Fame. London: Routledge.

Levý, J. (2012) Umèní překladu (The Art of Translation). Praha: Apostrof.

Mann, T. (1999) Doctor Faustus. New York: Vintage.

Marková, T. (2019) Modely pro analýzu překladu „hudby do slov” v cizojazyčné beletrii a jejích českých převodech (Models for analysing 'music rendered into words' in foreign language fiction and its Czech translations). AUC Philologica - Translatologica Pragensia, 2019 (1): 75-82.

Patchett, A. (2005) Bel Canto. New York: Harper Perennial.

Popovič, A. (1968) Teória umeleckého prekladu (Literary translation theory). Bratislava: Vydavatel'stvo Slovenskej akadémie vied.

Salmani, B. and Eghtesad, Z. (2015) An intersemiotic approach towards translation of cover designs in retranslated classic novels. Theory and Practice in Language Studies, 5 (6): 1185-1191.

Steinberg, A. (1982) Word and Music in the Novels of Andrey Bely. Cambridge: Cambridge University Press. 
Sterne, L. (2003) The Life and Opinions of Tristam Shandy, Gentleman. London: Penguin Books. Toury, G. (1995) Descriptive Translation Studies and Beyond. Amsterdam, Philadelphia: John Benjamins.

Tremain, R. (2001) Music and Silence. New York: Washington Square Press.

\section{BOOKS ANALYSED}

Seth, V. (1999) An Equal Music. London: Phoenix.

Tereza Marková (Mgr., DiS., PhD student) is currently on her way to her $\mathrm{PhD}$ in translation studies at Charles University, Prague, Czech Republic. Her research interests include literary translation, musical fiction, and intersemiotic translation.Email: vlaskova.tereza@email.cz 